University of Texas at Tyler

Scholar Works at UT Tyler

Presentations and Publications

Robert R. Muntz Library

$10-28-2014$

\title{
Role Reinvention, Structural Defense, or Resigned Surrender: Institutional Approaches to Technological Change and Reference Librarianship
}

Tiffany LeMaistre

tiff.lemaistre@gmail.com

Rebecka L. Embry

Lindsey L. Van Zandt

Diane E. Bailey

Follow this and additional works at: https://scholarworks.uttyler.edu/pres_pubs

Part of the Library and Information Science Commons

\section{Recommended Citation}

LeMaistre, Tiffany; Embry, Rebecka L.; Van Zandt, Lindsey L.; and Bailey, Diane E., "Role Reinvention, Structural Defense, or Resigned Surrender: Institutional Approaches to Technological Change and Reference Librarianship" (2014). Presentations and Publications. Paper 5.

http://hdl.handle.net/10950/231

This Article is brought to you for free and open access by the Robert R. Muntz Library at Scholar Works at UT Tyler. It has been accepted for inclusion in Presentations and Publications by an authorized administrator of Scholar Works at UT Tyler. For more information, please contact tbianchi@uttyler.edu. 


\section{CHICAGO JOURNALS}

Role Reinvention, Structural Defense, or Resigned Surrender: Institutional Approaches to Technological Change and Reference Librarianship

Author(s): Tiffany LeMaistre, Rebecka L. Embry, Lindsey L. Van Zandt, and Diane E. Bailey

Source: The Library Quarterly, Vol. 82, No. 3 (July 2012), pp. 241-275

Published by: The University of Chicago Press

Stable URL: http://www.jstor.org/stable/10.1086/665932

Accessed: 06/08/2014 15:59

Your use of the JSTOR archive indicates your acceptance of the Terms \& Conditions of Use, available at http://www.jstor.org/page/info/about/policies/terms.jsp

JSTOR is a not-for-profit service that helps scholars, researchers, and students discover, use, and build upon a wide range of content in a trusted digital archive. We use information technology and tools to increase productivity and facilitate new forms of scholarship. For more information about JSTOR, please contact support@jstor.org.

The University of Chicago Press is collaborating with JSTOR to digitize, preserve and extend access to The Library Quarterly. 


\title{
THE LIBRARY QUARTERLY
}

Volume 82

July 2012

Number 3

\section{ROLE REINVENTION, STRUCTURAL DEFENSE, OR RESIGNED SURRENDER: INSTITUTIONAL APPROACHES TO TECHNOLOGICAL CHANGE AND REFERENCE LIBRARIANSHIP}

\author{
Tiffany LeMaistre, ${ }^{1}$ Rebecka L. Embry, ${ }^{2}$ Lindsey L. Van Zandt, ${ }^{3}$ and \\ Diane E. Bailey ${ }^{4}$
}

In a comparative field study of ten libraries, we show how technological advances in electronic and digital resources have led to an onslaught of technology questions at the reference desk while prompting new and challenging work away from the desk. Libraries in our sample varied in their approaches to dealing with technological change, with institutional factors appearing to strongly shape their choice. Large, four-year academic libraries adopted a role reinvention approach that reduced reference librarians' desk hours and permitted librarians to follow creative, often technical, pursuits. Small, four-year academic libraries took a structural defense approach that maintained the sanctity of the reference desk as the locus for substantive reference questions. Two-year academic and public libraries followed a resigned surrender approach where reference librarians staffed busy desks and were inundated with patron requests to aid with computer equipment. We discuss the implications of each approach for the work of reference librarians.

1. The University of Texas at Tyler Libraries, 3900 University Blvd. Tyler, TX 75799-0001; E-mail tlemaistre@uttyler.edu.

2. Pope County Library System, 116 East 3rd Street Russellville, AR 72801; E-mail rebeckaembry@gmail.com.

3. Lone Star College CyFair Library, 9191 Barker Cypress Road, Cypress, TX 77433; E-mail lindseyvz@gmail.com.

4. University of Texas at Austin, School of Information, 1616 Guadalupe Suite \#5.202, Austin, TX 78701-1213; E-mail diane.bailey@ischool.utexas.edu.

[Library Quarterly, vol. 82, no. 3, pp. 241-275]

(C) 2012 by The University of Chicago. All rights reserved. 0024-2519/2012/8203-0001\$10.00 


\section{Introduction}

The reference interview has long stood at the heart of what it means to be a reference librarian. To conduct a reference interview is to help a patron refine, for the sake of the best possible answer, an information query [1,2]. Contemporary texts on reference librarianship continue to view the reference interview as a key element in this work [3]. Even as technologies have changed, the reference interview has persisted, adapting to new communication channels, such as chat and e-mail reference, and its successful conduct remains, scholars claim, a key competence among librarians [4-7].

Yet, studies indicate that the number of reference questions has declined dramatically in recent years [8,9]. Moreover, substantive reference questionsthe kind that, unlike a directional question or a circulation question, would prompt a reference interview-are but a small fraction of the questions posed to reference librarians $[10,11]$. Researchers often blame technological change for the decline in reference questions and of substantive reference questions in particular $[12,13]$. The Internet, electronic databases, and online instruction aids are among the technologies that purportedly contribute to this decline by providing patrons with the means to discover and retrieve information on their own, absent direct help from a reference librarian.

Although no statistics exist that would track the number of reference librarians employed over time, the total librarian workforce has remained rather constant in recent years and is projected to remain stable [14]. Herein lies a puzzle. If the number of reference questions has fallen but the number of librarians has not, then one is left to infer that the work of librarians, and, in particular, reference librarians, has changed. Existing research provides few clues, however, as to what reference librarians do while at the desk or away from it, how what they do has changed over time, or to what extent and in what ways advances in library and information technology have engendered change in the work of librarians. Some research suggests that providing reference service-be it answering questions in discrete one-to-one interactions at the desk or providing the larger infrastructure for independent searchremains among librarians' most highly valued tasks $[15,16]$. As evidence, the average amount of time that reference librarians reported spending on this task in Sonja McAbee and John Graham's [16] survey of twenty-one mediumsized academic libraries was nearly identical to what librarians in Rebecca Schreiner-Robles and Malcolm Germann's [17] survey of such libraries reported more than a decade and a half earlier. What little we do know about changes to reference work comes to us indirectly, largely through analyses of job advertisements over time that speak, for example, to the greater need for technical skills among new entrants to the field as compared to the past [e.g., 13, 18, 19].

In this article, we investigate technology-induced occupational change 
among reference librarians through an empirical study that draws upon ethnographic methods of observation and interviews at ten Texas libraries. We pay particular attention to institutional context through a purposive sample of libraries in public, four-year degree (or more) academic, and two-year degree (or less) academic settings. Most prior empirical studies of the work of reference librarians restricted their sample to a single institutional context, for instance, McAbee and Graham's [16] study of academic libraries and Beverly Lynch's [20] study of public libraries. Our comparative design allows us to explore differences in how the work of reference librarians has changed across type of library. In particular, our design permits us to probe how institutional differences in such areas as patron audiences, library mandates, and financial situations may have shaped differences in how the role of reference librarian has evolved in the wake of technological advance. We set the stage for our inquiry by considering the evidence in the literature of change in reference librarianship, focusing on the period that spans roughly the development of the World Wide Web to today.

\section{The Changing Landscape of Reference Librarianship}

The most fundamental change afoot in reference librarianship concerns the number of questions that patrons pose. Over the past two decades, the number of patron questions-known as transactions-across institutional contexts either declined or leveled out. Every two years the National Center for Education Statistics (NCES) administers the Academic Library Survey (ALS) to between roughly 3,700 and 4,200 participating institutions. According to NCES/ALS statistics, the number of transactions at four-year degree (or more) and two-year degree (or less) academic libraries has been on a general decline for the past fifteen years. ${ }^{5}$ At four-year academic libraries, the number rose between 1996 and 1998 and then fell precipitously through 2008, from a high of nearly 700 transactions per week to a low of less than 300. (See fig. 1.)

Although not as striking, the number of transactions at two-year academic libraries similarly shows an overall decline over this time period (see fig. 2). As figures 1 and 2 illustrate, these declines came amid rising library attendance. In short, the per capita decrease was even higher than the absolute decrease. The NCES/ALS statistics are corroborated by Association

5. Hereafter, we refer to these types of libraries as four-year and two-year academic libraries, respectively. We derive this categorization from NCES/ALS codes for the institution housing the library. 


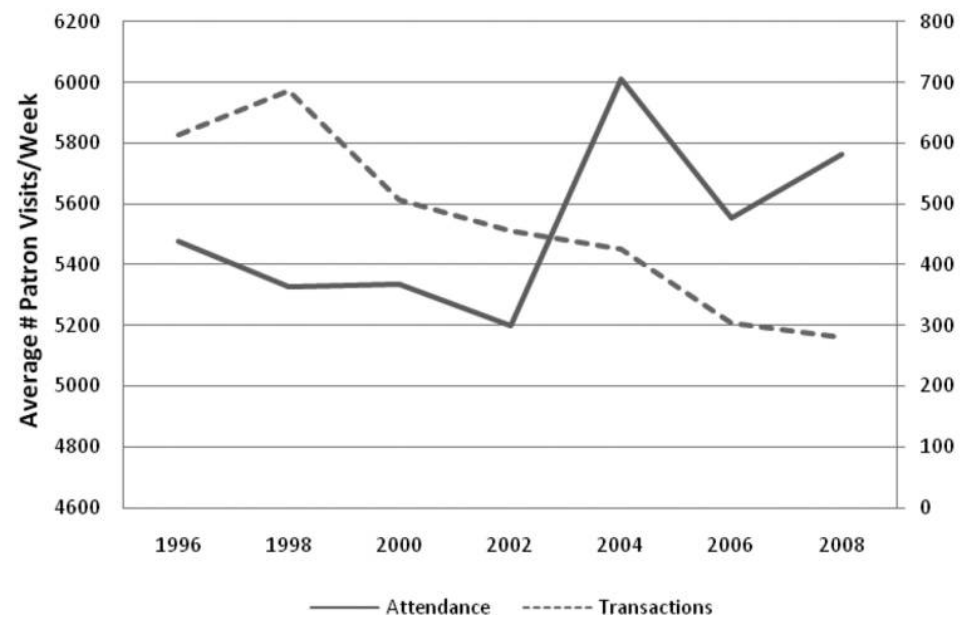

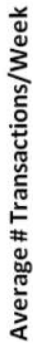

FIG. 1.-Four-year academic library attendance and transactions by year (color online).

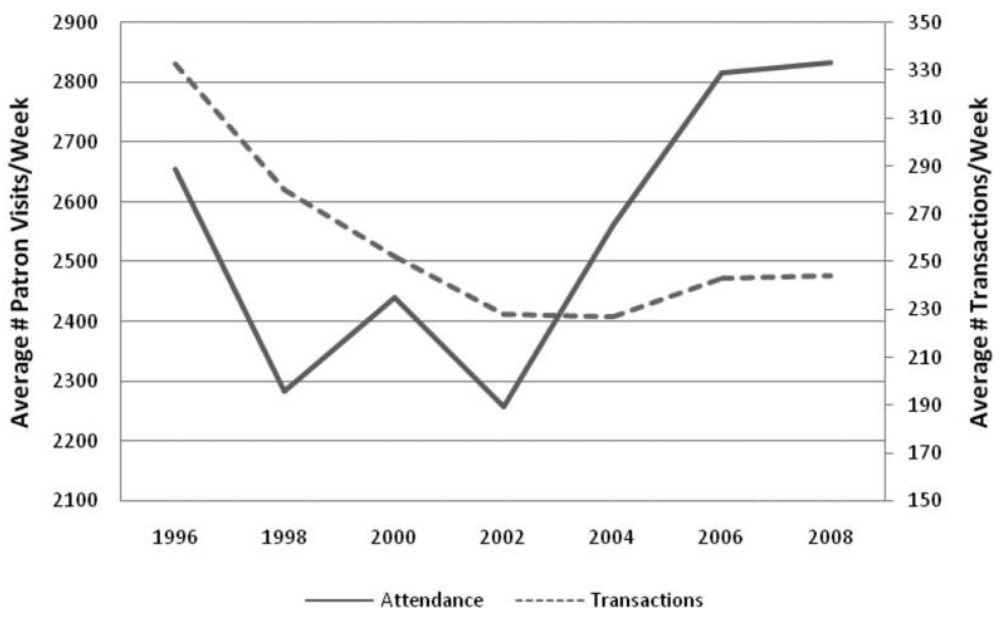

Fig. 2.-Two-year academic library attendance and transactions by year (color online). 


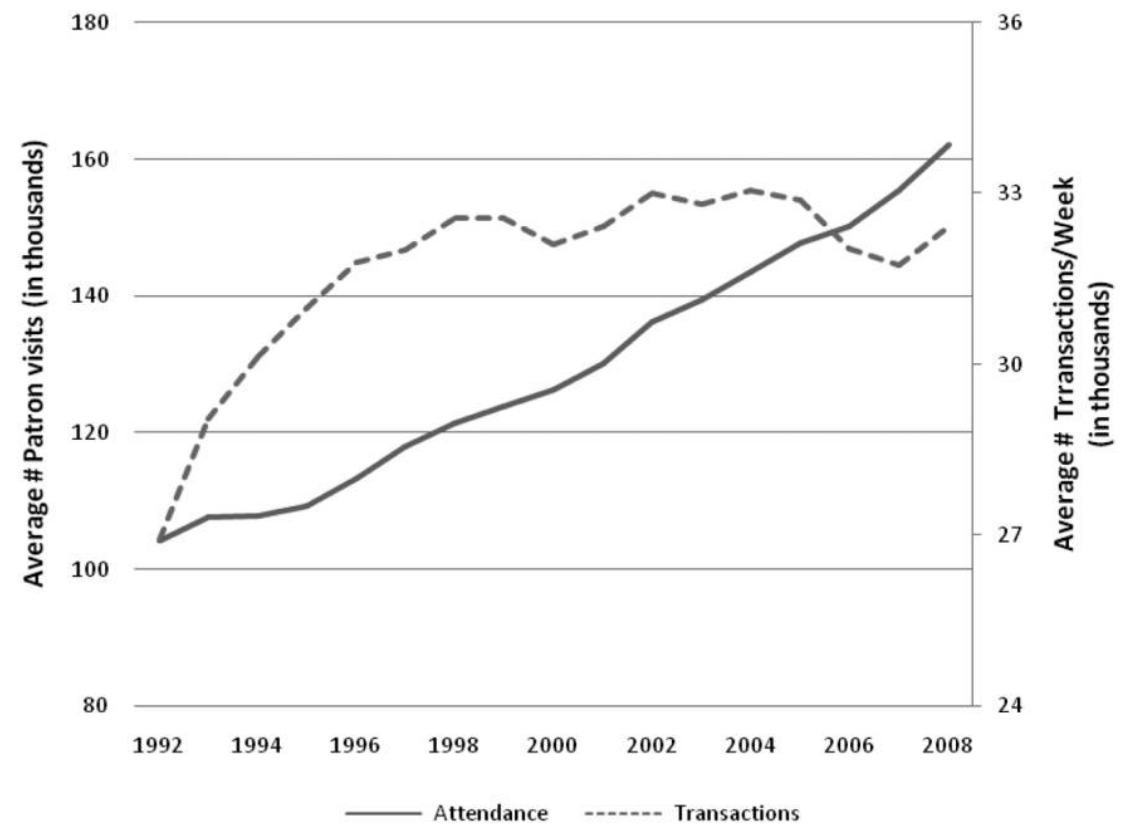

FIG. 3.-Public library attendance and transactions by year (color online)

of Research Libraries (ARL) statistics gathered from 123 members. According to the ARL data, the number of transactions at research libraries declined by 48 percent between 1991 and 2005 .

The story is only slightly better at public libraries. Figure 3, which displays data from the Institute of Museum and Library Services' (IMLS) Public Library Survey (PLS) of roughly 8,900 to 9,200 participating libraries, reveals that the number of transactions, though rising from 1992 until about 2002, leveled out since then. As in academic libraries, the number of transactions in public libraries did not keep pace with rising library attendance, as seen in figure 3 .

Despite an overall decline in the number of transactions over more than a decade and a half, the number of academic and public librarians has remained fairly constant. The number of librarians working at four-year academic libraries between 1996 and 2008 decreased only slightly (see fig. 4). At two-year academic libraries, the number of employed librarians did not change between 1996 and 2008 (see fig. 5). However, figures 4 and 5 reveal that the number of paid nonprofessional staff and student employees declined during this period across both academic library contexts. In public libraries, the workforce grew steadily from 1992 to 2008, with the increase 


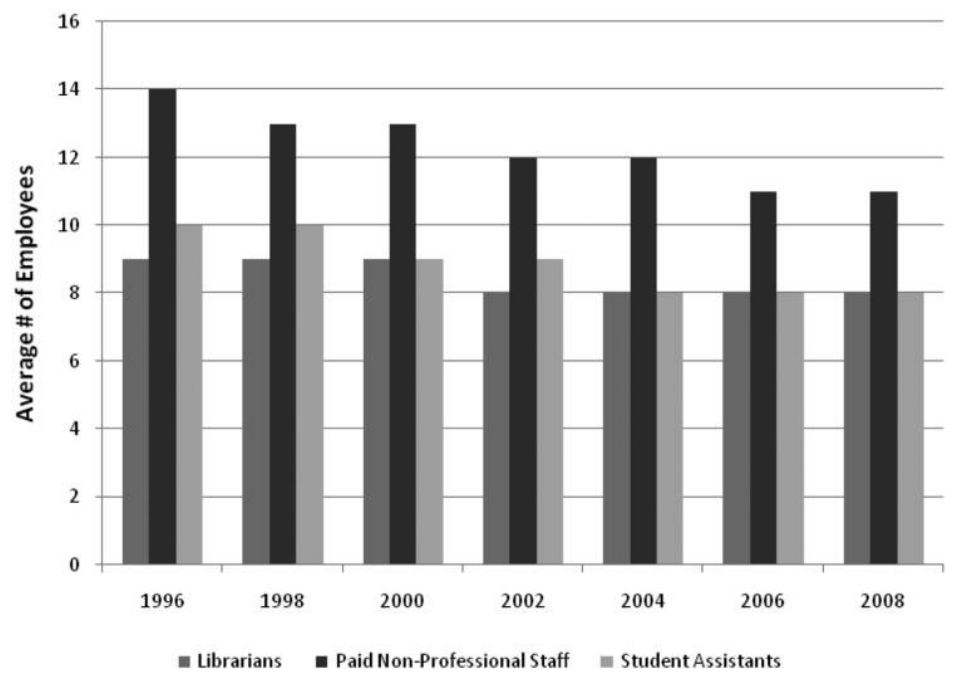

Fig. 4.-Four-year academic library workforce by year and type of employee (color online).

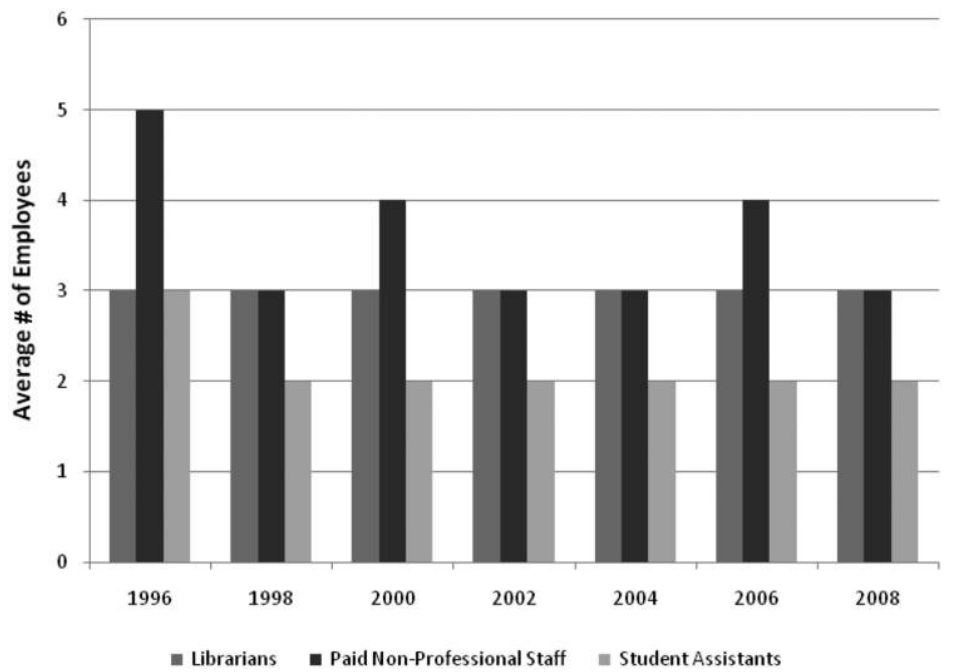

Fig. 5.-Two-year academic library workforce by year and type of employee (color online). 


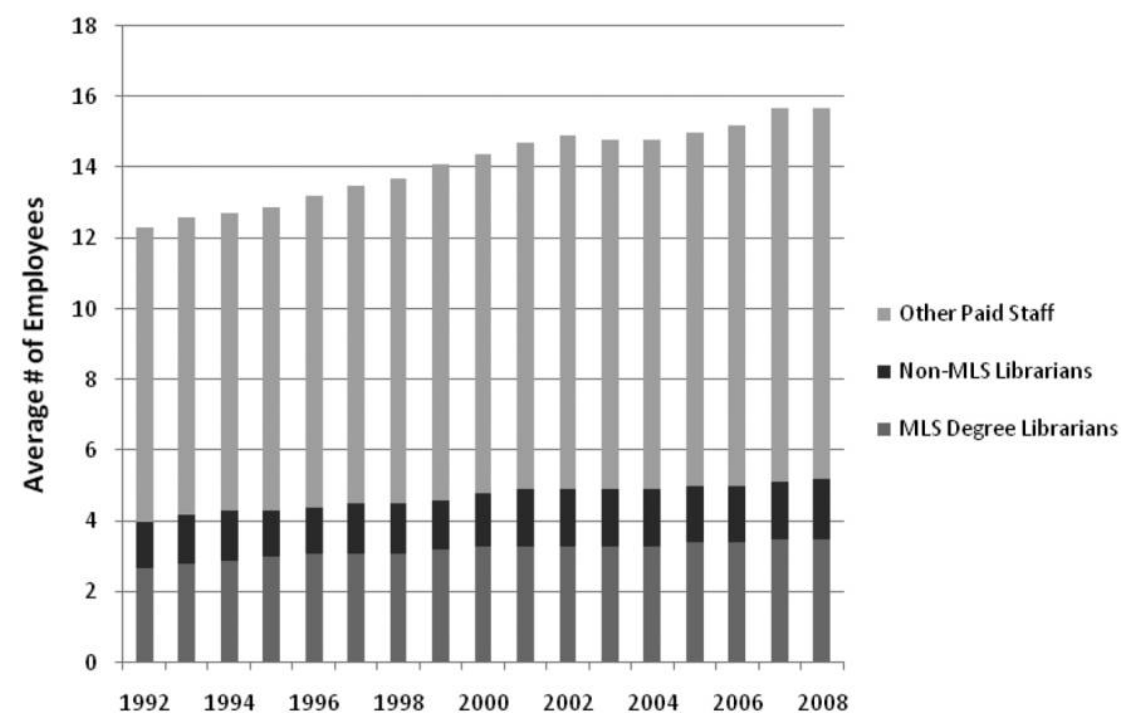

FIG. 6.-Public library workforce by year and type of staff (color online)

largely centered on the nonprofessional paid staff. Notably, MLS-degreed librarians, while not increasing in numbers, suffered no decline in employment (see fig. 6).

Most writers and thinkers point to technological change to explain why reference work is changing and why, in particular, the number of reference questions is declining. Although today computers are ubiquitous in libraries, three decades ago they were rare. In the early 1980s, Robert Hauptman [21] reported from a survey on computer use that only the minority of reference desks were furnished with computers. By the turn of the century, however, librarians in public and academic libraries alike reported altered jobs in the face of technological change. The changes were significant enough that some librarians were worried that technology would negatively affect their job and perhaps even displace them [22]. A 2001 survey investigating the impact of technology on cultural institutions found that 99 percent of public libraries and 100 percent of academic libraries employed computers, software, or telecommunication networks in their day-to-day operations [23]. Today even poor libraries are able to make at least a few computers and Internet access available to patrons for their information needs [24].

In a sense, librarianship, like many occupations, has long harbored beliefs that technological advances would dramatically, and negatively, remake work 
(e.g., [25]). As a case in point, reference librarianship was barely established as a field when Justin Winsor, head of Harvard College Library in the late 1800 s, proclaimed the subject catalog such an efficient tool for patron search that it rendered library staff unnecessary [26, pp. 52-55]. Winsor's prediction ultimately proved wrong, in part because technology has considerable potential to wreak positive changes in occupations by opening up new avenues of responsibility and activity [27].

In the case of reference librarianship, the rise of electronic and digital resources may have improved work by freeing librarians from answering simple questions. The remaining questions, by this logic, should be more unique, complex, and challenging, and, as a result, should consume a significant portion of reference librarians' time. In general, scholars refer to such questions as "substantive" reference questions. As defined by Lynch [20, p. 127], substantive transactions begin "with a request for factual information, for help in finding material on a specific subject, for help in interpreting something in an information source, [or] for help in locating a specific item which is not a separate bibliographical unit."

Some evidence exists to show that the logic of substantive questions' new dominion does not hold. A recent analysis of nearly 7,000 transactions at the reference desk of a small university revealed that just over a quarter were substantive questions [11]. Deborah Henry and Tina Neville's [10] findings at another small university library show yet a smaller percentage: among more than 5,000 transactions, no more than 12 percent were substantive. These figures from recent studies stand in sharp contrast to values derived in earlier research. Analyzing large samples of desk transactions, both Lynch [20], in a study of four public libraries, and Robert Balay and Christine Andrew [28], in a study of a large academic library, found that the percentage of substantive reference questions was 40 percent or slightly greater. In short, not only has the overall number of reference transactions decreased but among the remaining transactions, it appears that the percentage of substantive questions has declined.

What then, are reference librarians doing if they are not answering timeconsuming substantive reference questions? Several sources indicate that reference librarians today spend the majority of their time away from the reference desk and that their responsibilities now extend into new, often technological, domains. New duties include such tasks as creating web documents from instructional materials, developing and managing access to electronic resources, serving as webmasters, and acting as faculty liaisons [29]. The off-desk task whose increasing significance scholars cite perhaps most often is that of instruction, especially in the context of information literacy classes that teach patrons how to use electronic and digital resources $[9,30]$.

Data from the NCES/ALS provide partial support for the claim of in- 
creased instruction, with presentations up 20 percent at four-year academic libraries between 1996 and 2008. Presentations at two-year academic libraries, however, remained rather constant over this period. No similar data on presentations over time are available for public libraries, and it may be that instruction looms less large in those settings. Librarians have argued for some time, however, that changes in technology would warrant changes in their skill set, including instruction skills [31, 32]. Indeed, Beverly Lynch and Kimberley Robles Smith [19], who analyzed job ads over a twenty-five year period from 1973 to 1998, documented a rise in the number of ads that listed instruction among a position's responsibilities. By the 1990s, each job ad for a reference librarian in that study's sample included a preference for instruction capabilities.

Traditionally, character traits, not instruction skills, loomed large among the requirements of reference work. In the predigital era, Martha Boaz [33, pp. 75-76] wrote that an ideal librarian should possess five qualities: "vitality, courage, intelligence, sensitiveness, and dedication." Similarly, Carleton Kenyon [34] listed intellectual curiosity, resourcefulness, vision, sympathy, humility, and imagination among the personal traits that reference librarians ought to possess. Personal traits as skill requirements persist in practitioner circles (see [35]) and recent literature. As evidence, Joann Devries and Patricia Rodkewich [36] listed approachability, curiosity, intuition, empathy, persistence, logical thought patterns, and ability to work with others among the necessary traits for reference librarians.

Technical skills began to appear as a complement to such personal qualities beginning about 1990 [37, 38]. As late as 1996, however, technical skills still failed to routinely count among the top competencies demanded by this work. In a survey of 736 working librarians (graduates of MLS programs), Lois Buttlar and Rosemary Du Mont [15] reported that respondents ranked knowledge of sources, managing a collection, conducting a reference interview, communicating effectively in writing, and applying critical thinking skills to library problems as the top five essential competencies; notably absent were technical skills.

By the turn of the century, however, technical skills were firmly rooted among the top competencies for reference librarians. Most of the evidence for this shift comes from studies that analyzed job ads. Gary White [18], who examined ads for academic librarians between 1990 and 1998, found that computer skills ranked in the top five required skills or qualifications during this period no matter if the advertised position was in a science, business, or social science library. In an analysis of 906 job ads from the American Library Association's Job List between October 2007 and March 2008, Janie Mathews and Harold Pardue [39] reported that 72 percent of the ads required at least one information technology skill. The top four such skills appearing in the ads were web development, project manage- 
ment, systems development, and systems applications. Presumably, basic technical skills, such as operating computer databases, were so ingrained in librarians' skill sets by that point that they did not warrant mention in job ads. Hanrong Wang, Yingqi Tang, and Carley Knight [40] similarly analyzed job ads for academic librarian positions from 1966 through 2009. They found that whereas job titles in the early years were few in number and were typified by titles such as bibliographer and readers' service librarian, by the end of the period the number of titles had grown considerably and reflected a range of technical specialties, including web service librarian, online service librarian, electronic information librarian, and digital information service librarian.

If, in fact, reference librarians are increasingly engaging in off-desk activities that require a changing set of skills, then someone else must be staffing the reference desk in their absence. For more than two decades, that someone else has often been a paraprofessional, as Jack O'Gorman and Barry Trott [41] noted in the case of public libraries and other scholars [42, 43] found among academic libraries. Although some writers have decried the use of paraprofessionals (e.g., [44]), several studies have shown that a trained nonprofessional could answer the majority of patrons' questions. For example, in a study of an undergraduate reference desk, Jeffrey St. Clair and Rao Aluri [45] determined that a trained nonprofessional could answer 80 percent of the questions posed. Debbie Dinkins and Susan Ryan [46] similarly found that a newly trained paraprofessional on an academic university reference desk could handle all but 7 percent of received questions.

In sum, data from the NCES/ALS and IMLS/PLS as well as the librarianship literature over the past decade and a half suggest that the work of reference librarians has been greatly transformed in the wake of technological changes that have placed substantial electronic and digital information resources at the fingertips of patrons. Mila Su [47] has suggested that similar technological changes in circulation, including self check-out and user-generated renewals, might prime the pump for organizational restructuring in libraries, including merging circulation with reference.

Others have put forward more dire predictions. Keith Ewing and Robert Hauptman [48, p. 4] prompted controversy when they deemed reference librarianship obsolete. This obsolescence, they declared, was in part due to technological change and in part simply overdue. Many reference questions, being directional or simplistic, never required sophisticated interviewing skills or deep subject knowledge in the first place. They wrote: "The highly acclaimed, frequently cited reference interview-the one that requires honed skills, knowledge of behavioral and motivational paradigms, acute senses, and a semiscripted dialogue to discern the 'real question 
behind the question'-is a largely historically developed construct to support the need for a trained professional."

In a more positive light, some scholars have concluded that reference librarians have simply undergone-and survived-a fundamental shift in occupational identity. Based on interview results, Devries and Rodkewich [36, p. 212] summed up the differences in what it took to be a reference librarian in the short span separating 1990 from 1996: "Reference librarians are no longer seeing themselves as providers of a specific piece of information. They are now facilitators; they are guides." In a similar vein, Debbie Smith and Victor Oliva [49] argued that changes in technology have rendered reference librarians less specialists in particular subject areas and more generalists who can find information in a wide variety of domains.

Although scholars and practitioners concur that technology has transformed the job of the reference librarian, exactly how it has done so, and to what extent, remains unclear. These questions lie unanswered in large part because the methods of many studies have held the phenomenon of interest-a reference librarian at work-at arm's length. Large-scale surveys and analyses of job ads over time are frequent study designs. Over the past thirty-five years, studies that involved direct observation of librarians at work have been rare. Even less prevalent have been comparative studies that investigate the extent to which the impact of technological change on the work of reference librarians differs by type of institution.

With these points in mind, we undertook the direct study of reference librarians at work in the library across public, four-year academic, and twoyear academic libraries. Our goal was to understand what reference librarians do, what skills they require, how technology has shaped their work, and the extent to which institutional forces may have mediated this shaping.

Methods

Research Design

We gathered data from ten libraries across Texas, stretching from San Marcos in the south to Dallas in the north and Houston in the east, with a concentration in Austin and its environs. We designed our sample to span three institutional types: public, four-year academic, and two-year academic. In choosing these ten libraries, we aimed for a mix of academic (seven) and public (three) institutions, a balance of four-year (four) versus two-year (three) degree-granting institutions among the academic libraries, and a balance of small (five) versus large (five) institutions overall. The diversity of settings represented by our sample facilitates the exploration 
TABLE 1

Libraries in Our Study by Setting, Type, and Enrollment/Population

\begin{tabular}{lllc}
\hline \hline Name* & Setting & \multicolumn{1}{c}{ Type } & Enrollment/Population ${ }^{\dagger}$ \\
\hline Big Research & Academic & Large four-year & 46,537 \\
Big Comprehensive & Academic & Large four-year & 24,245 \\
Small Research & Academic & Small four-year & 9,687 \\
Small Comprehensive & Academic & Small four-year & 4,295 \\
Big Metro Associate & Academic & Two-year & 27,669 \\
Big City Associate & Academic & Two-year & 21,115 \\
Small Associate & Academic & Two-year & 3,856 \\
Big City Public & Public & Multiple outlets ${ }^{\dagger}$ & 465,622 \\
Small City Public & Public & Single outlet & 30,923 \\
Small Town Public & Public & Single outlet & 14,842 \\
\hline
\end{tabular}

* All names are pseudonyms.

$\uparrow$ For academic libraries, values are from the 2008 NCES/ALS and reflect full-time equivalent students. For public libraries, values are from the 2008 IMLS/PLS and reflect the population of the legal service area.

$\ddagger$ We studied the main branch only, which handled reference services for all branches.

of institutional differences in such areas as patron audiences, library mandates, and financial situations that may have shaped differences in the evolution of the role of reference librarian. Table 1 details the settings, type, and enrollment/population figures for libraries in our study. We contacted directors or librarians at each library to enlist their library's participation in the study. These individuals suggested to us reference librarians who might serve as informants. We then contacted the librarians to solicit their voluntary participation. Among our final sample, over 80 percent of our fifty-seven informants were Caucasian; a similar percentage were female. About 45 percent of these individuals held the job title of reference librarians; other representative titles included instruction librarian and public service librarian.

To permit a nuanced examination of the work of reference librarians that would investigate not only what they do but also what factors shaped their roles and tasks over time, we conducted a qualitative study that featured ethnographic techniques of observation and interviews to collect data. Our focus on observational data sets our work apart from most prior studies of transactions, which have relied on informant logs maintained at the desk [11, 28, 50]. Our observations made clear to us that such logs often are incomplete.

\section{Data Collection}

Our team consisted of four master's students and one professor who trained the students in ethnographic techniques. Working singly, the students observed reference librarians at work both on and off the reference 
TABLE 2

Study Informants by Type of Data Collection

\begin{tabular}{|c|c|c|c|c|}
\hline \multirow[b]{2}{*}{ Library } & \multicolumn{2}{|c|}{ Observations } & \multicolumn{2}{|c|}{ Interviews } \\
\hline & $\begin{array}{c}\text { No. } \\
\text { On-Desk } \\
\text { Informants }\end{array}$ & $\begin{array}{c}\text { No. } \\
\text { Off-Desk } \\
\text { Informants }\end{array}$ & $\begin{array}{c}\text { No. } \\
\text { Interviews }\end{array}$ & $\begin{array}{c}\text { Tenure at } \\
\text { Library } \\
\text { (in Years) }\end{array}$ \\
\hline Big Research & 6 & 1 & 2 & $25^{*}$ \\
\hline Small Research & 2 & 2 & 1 & 25 \\
\hline Big Comprehensive & 5 & 4 & 1 & 20 \\
\hline Small Comprehensive & 5 & 1 & 1 & 32 \\
\hline Big Metro Associate & 3 & 1 & 1 & 32 \\
\hline Big City Associate & 3 & 1 & 1 & 27 \\
\hline Small Associate & 4 & 2 & 1 & 14 \\
\hline Big City Public & 7 & 2 & 1 & 25 \\
\hline Small City Public & 3 & 0 & 1 & $3^{\dagger}$ \\
\hline Small Town Public & 2 & 1 & 2 & $15^{*}$ \\
\hline Total no. informants (by library) & 40 & 15 & 12 & \\
\hline Total no. unique informants (for study) & 57 & & & \\
\hline
\end{tabular}

* Values are for the primary informant only.

+ Although this informant's tenure was brief, she was knowledgeable about the library's history and had worked as a public librarian for 24 years.

desk, as summarized in table 2, which shows the number of informants for each type of observation. At each library, we conducted between four and seven observation sessions. One student was the primary observer at each site; a second student conducted at least one observation at each site to ensure coherence in methods, with the exception of Big Metro Associate, where a single student conducted all of the observations due to its distance from our site. Team discussions of our observations at each library further ensured consistency in our approach. In total, we spent six to seven hours at each library observing reference librarians at the reference desk, with each session lasting between an hour and a half and four hours. We observed chat reference at libraries where it was offered, either away from the reference desk or at it. We also observed phone, e-mail, and instant message transactions, all at the desk. Overall, virtual transactions accounted for 11 percent of total transactions, with phone queries constituting more than 70 percent of all virtual transactions. In other words, chat, e-mail, and instant message queries were only 3 percent of the total transactions.

Across the ten libraries, we conducted a total of forty-six on-desk observations, or seventy-five hours of observation. We made an effort to observe academic libraries during the fall semester and public libraries during the summer based on informal feedback from informants that these were the busiest times of year. We varied our observations by time of day as well. We also observed off-desk activities at each site, with the exception of Small 
City Public Library, whose new director opted out of the study at that point. At each of the remaining nine libraries, we conducted between one and two off-desk observation sessions, ranging in length from one to two hours. During these sessions, informants typically worked at desks in offices in the library, but they also met with colleagues and patrons in small conference areas or held classes in larger rooms. The observer trailed the informant during the off-desk observation across all activities. Across the nine libraries, we conducted a total of fifteen off-desk observations, or eighteen hours of observation. We have fewer off-desk than on-desk observations because the former were more difficult to schedule and because the libraries were more accustomed to having observers (often student interns) at the desk. To compensate, we asked our informants detailed questions about their off-desk activities during interviews and during breaks in on-desk activity.

During on-desk and off-desk observations, we took extensive field notes. Immediately after each observation session, we expanded the field notes into full narratives that captured and richly described all of the actions of the informant, as well as all discussions. In the case of phone conversations, we documented the librarian's dialogue. Upon the conclusion of the call, we were sometimes able to gain from the librarian the patron's specific inquiry.

We conducted historical semistructured interviews at each library to obtain an understanding of how, and to what extent, the work of reference librarians has changed. For our interviews, we targeted informants who had a long tenure at their library because we wanted individuals who could detail for us changes that had taken place over time. In all but one case, the interview informants were distinct from the observation informants. We conducted one interview at each library with two exceptions. At Big Research Library, we conducted a second interview when an observation informant provided us with historical information about the library. At Small Town Public Library, we conducted a second interview with another individual to gain specific information that our primary informant lacked. Table 2 summarizes the number of interviews at each library as well as the tenure of the informant for the primary interview.

We audiotaped and transcribed the interviews, which lasted for one hour, on average. Our questions prompted informants to describe the library's operations, physical layout, organization, and technology, in addition to reference librarians' roles and tasks, as informants remembered from when they first began working there. We began with a prompt to recall an earlier era: "I'd like you to think of the time here at the library before computers were prevalent in reference and tell me what it was like for reference then." Subsequent questions probed what changes had occurred over time in the library, such as new technology acquisitions and library renovations. Ques- 
tions included, "Can you tell me how things started to change?" and "What was the triggering event that started to cause changes in reference?" For each change that the informant recalled, we explored what other factors (e.g., reference librarians' role, library physical layout) had changed in conjunction with that event. Example questions included "What was the physical layout of the reference desk area at that time?" and "What new tasks did reference librarians perform after that?"

\section{Data Analysis}

We employed a grounded theory approach to analysis that involved repeated examination of our data $[51,52]$. Our team began analysis of ondesk activity by reading through the field notes of each on-desk observation to identify and isolate transactions. The beginning of a transaction was marked by a patron coming to the desk and asking a question, the patron e-mailing, phoning, or messaging the desk, the librarian asking a patron if the patron needed assistance, or the librarian asking a patron to do something. The end of a transaction was marked by either the patron or the librarian terminating the conversation, as when the patron walked away from the desk or the librarian hung up the phone. We identified a total of 662 transactions across the observations of all ten libraries. By dividing the number of transactions at each library by the number of hours we observed at its desk, we were able to calculate a measure of how busy each reference desk was.

We conducted open coding [53] of our on-desk field notes, analyzing a random subset of the field notes to distinguish among the types of transactions. Seven categories emerged from this exercise: circulation, conversation, information, holdings, operations, technology, and reference. In addition to questions about checking out materials, circulation transactions reflected questions about such things as library accounts, lost and found, and summer reading programs. Conversation transactions involved casual comments, such as thanking the librarian for earlier help. Directional requests as well as questions about library policies constituted information transactions. Questions about whether the library owned a specific resource or where it was located constituted holdings transactions. Operations transactions included disciplinary requests (e.g., asking the librarian to intervene with a patron talking loudly on a cell phone), as well as requests to reserve rooms or perform a special function (e.g., asking the librarian to straighten the stacks). We divided technology transactions into five categories: computer reservations, equipment (e.g., fax machines, printers), Internet, library resources (e.g., electronic databases), and software (e.g., Word or Excel). To count in this category, the query had to be about how to use the technology, not whether the patron ought to use it or not. Finally, reference transactions included ready reference questions as well as more in-depth queries involving citations, the quality or appropriateness of 
resources, genealogy/obituaries, specific topics (e.g., Greek gods), and aid with practical problems (e.g., repairing a car). These seven categories served as codes that the first author used in Atlas.ti software to code transactions. We classified as "unclear" a small number of transactions (2 percent) due to insufficient information (e.g., a muffled question at a busy desk).

We further analyzed reference transactions to determine what percentage of them resulted in reference interviews. Past empirical studies differed on how to define and count reference interviews. Some researchers used duration as the defining trait and then counted as interviews all reference transactions that met an appropriate time limit. For example, Rhonda Boyd [50] and Linda Salisbury, Sylvia Toombs, and Elizabeth Kelly [54] defined reference interviews as reference transactions that lasted ten or more minutes. Placing the bar somewhat lower, but not explicitly defining a reference interview, Theresa Arndt [55] suggested that reference transactions answered in less than five minutes may not require a professional librarian. Other researchers employed classification schemes that ranked reference questions based on the skills and time required to answer them. Questions that demanded higher skills and more time achieved higher ranks and were deemed substantive enough to count as reference interviews. For example, Henry and Neville [10] used schemes by Katz and Warner to code questions that required lengthy and detailed assistance, possibly from a specialist (Katz, level 4); that demanded formulation of a strategy, selection of resources, and potentially an individual subject approach (Warner, level 3); or that involved longer encounters outside regular desk duty (Warner, level 4). Still other researchers distinguished reference interviews from other reference transactions by counting the number of resources needed for their answer [11].

We opted for a two-pronged approach. First, we measured the time each reference transaction took and then used five-minute time units to build a histogram of questions based on duration. Examining the entire histogram gave us a sense for the distribution of transactions without a priori setting an arbitrary threshold for inclusion as a reference interview. Second, we followed Lynch [20] by examining whether, in response to a question posed by a patron, the librarian responded with a question. For each reference transaction, we counted the number of questions the reference librarian posed and built a second histogram with these results. Employing a question-question structure helped us to ascertain whether or not the librarian conducted an interview as opposed to simply having taken a long time to find materials.

We next analyzed off-desk activities by drawing upon the two sources of data that contained the most information about them: our direct observations of informants as they performed off-desk activities and our historical interviews, in which informants often mentioned off-desk activities. We con- 
ducted open coding of each off-desk observation except the library instruction classes. Because library instruction classes covered a large block of time in which the informant was carrying out a single activity, they needed no additional coding.

We analyzed a random subset of the off-desk observations to distinguish among the types of activities that transpired. Nine categories emerged from this exercise: collection development, library instruction, patron meetings, technical work, outreach, library tours, committee membership, cataloging, and interlibrary loan. Collection development activities featured reference librarians acting as a bibliographer. The planning and teaching of information literacy courses constituted library instruction activities. Patron meetings involved the reference librarian scheduling set times to meet with individuals away from the desk. Creating and managing library websites and blogs, building virtual library communities, and programming software applications were all forms of technical work activities. Outreach activities reflected efforts to draw patrons into the library through special events or to publicize library services. Library tours involved showing the facilities to patrons and other personnel. Committee membership activities reflected such tasks as attending meetings, including serving on committees of professional organizations. Cataloging involved creating and editing MARC records for the library's catalog. Processing patron requests for materials from another library constituted interlibrary loan activities. These nine categories served as codes that the second author used in Atlas.ti software to code each off-desk observation.

We coded historical interviews separately from the observations because the interviews featured discussions of activities, not their actual completion. For this reason, the historical interviews provided an opportunity to probe how librarians' activities changed over time. Themes that arose in this coding included the changing content of questions at the desk, the importance of desk layout and proximity to computers in shaping desk questions, libraries' varying approaches to change, and changes in reference librarians' roles and skills. Combined, the coding of the observations and historical interviews permitted us to document the set of activities in which reference librarians at each library engaged and, more broadly, to create a picture of how reference librarians spent their time at and away from the reference desk.

\section{Results}

The ten libraries we studied encountered similar advances in reference technology that mirrored changes that David Tyckoson [56], Carol Singer [57], and others have documented more broadly. Our informants' earliest memories 
involved CD-ROM databases installed on dedicated workstations in the 1980s. Although the number and type of databases increased with each passing year, most databases still required exact searches for title, author, or subject that typically warranted a librarian's aid. In the early 1990s, the World Wide Web appeared on the scene, with many libraries early adopters. Today, library patrons are able to conduct independent keyword searches on Internet-enabled computers that provide access to an abundance of electronic resources and that have become, as a result, a central feature of each library in our sample.

We present our results about the impact of these technological changes in three sections. The first section details how technology proved a mundane interloper at the reference desk by degrading the required skills of reference librarians, and ultimately those who would join them in staffing the desk, through two primary mechanisms: (1) by providing patrons the means to search for information independently and (2) by increasing patron requests to deal with malfunctioning library equipment employed in independent searches, such as computers, printers, and scanners. The second section provides a brighter picture of technology's impact by showing how, off the desk, technology served as a creative muse that enabled reference librarians to engage in new and often creative technical work. Librarians engaged in such work-for example, by creating library web pages, maintaining blogs, or building virtual reading communities-to varying extents. The third section sums up institutional differences in how libraries dealt with technological change on and off the desk by outlining three approaches that libraries took and their resulting outcomes.

\section{Working at the Reference Desk: Technology as Mundane Interloper}

The reference desks in our sample varied widely in terms of how busy they were. Large four-year academic libraries and public libraries featured the busiest desks, with fourteen and sixteen transactions per hour on average, respectively. Two-year academic libraries followed, with eight transactions per hour on average. The fewest transactions per hour (four) occurred at the small four-year academic libraries.

To cope with demand, the busiest libraries employed individuals without MLS degrees to staff the reference desk during some hours. The large four-year academic libraries and two of the three public libraries employed paraprofessionals at the reference desk, something that none of the twoyear academic libraries and only one of the small four-year libraries did. Student employees were another option for the academic libraries. At Big Research, library administration introduced student employees to the desk primarily for economic reasons, based on the assumption that the librarians' expertise was not required to handle patrons' questions. A librarian 
explained: "Over time they emphasized hiring students over full-time staff members because they didn't have to give the part-time student employees the same health and retirement benefits. . . But we needed warm bodies to staff our desk. ... The library administration doesn't work the desk, they don't know the types of questions we get, but they sometimes think, 'Oh, they're just telling people where the bathrooms are down here.'"

Despite the addition of nonprofessional staff, the hours per week that reference librarians spent on the desk appeared largely unrelated to how busy the desk was. Time spent at the desk was shortest at the large fouryear academic libraries (ranging from one to eight hours per week) and longest at the public libraries (between eighteen and twenty hours per week), yet these two types of libraries had the busiest desks. At small fouryear academic libraries, librarians spent four to eight hours per week on the desk; librarians spent ten to fifteen hours per week on the desk at twoyear academic libraries.

For the large four-year academic libraries in our sample, the limited hours spent on the desk reflected a dramatic decrease from previous decades. In the 1990s, librarians at Big Comprehensive worked at the desk fifteen hours per week as compared to eight hours today. A librarian attributed the change to advances in technology that aid patrons in finding material on their own: "Students needed just a place to study. They didn't necessarily need us helping them. ... Patrons can get on the Internet and use the databases from their house."

But a technological explanation seems at best incomplete given that all libraries in our sample faced similar changes in the search tools available to patrons. By this logic, all of the libraries should have witnessed a drop in the hours that reference librarians spent at the desk, but they did not: hours remained largely unchanged for small four-year academic, two-year academic, and public libraries in our sample.

An alternative explanation attributes agency to library administration: reference librarians' hours on the desk may have been lowest among the large four-year libraries because managers there seemed intent on reinventing reference librarians' role. A Big Research librarian explained: "The library administration is encouraging all of the subject bibliographers to spend less time at the desk, spend more time in outreach, departmental meetings, meeting with faculty members in their offices, meeting with groups of students; those are thought of as more professional and more effective ways to spend professional time these days, partly because it leads to development opportunities, partly because we want, we need better relations with the faculty."

Four-year libraries may have led the charge in this role transformationemphasizing off-desk activities over on-desk ones-because, across our sample, 
TABLE 3

Prevalence of Transaction Types by Type of Library

\begin{tabular}{|c|c|c|c|c|c|}
\hline Transaction Type & $\begin{array}{c}\text { Large } \\
\text { Four-Year } \\
\text { Academic } \\
\text { Libraries } \\
\quad(\%)\end{array}$ & $\begin{array}{c}\text { Small } \\
\text { Four-Year } \\
\text { Academic } \\
\text { Libraries } \\
\quad(\%)\end{array}$ & $\begin{array}{c}\text { Two-Year } \\
\text { Academic } \\
\text { Libraries } \\
(\%)\end{array}$ & $\begin{array}{c}\text { Public } \\
\text { Libraries } \\
(\%)\end{array}$ & $\begin{array}{c}\text { Overall } \\
(\%)\end{array}$ \\
\hline Technology & 19 & 13 & 37 & 39 & 32 \\
\hline Circulation & 15 & 19 & 14 & 17 & 16 \\
\hline Holdings & 24 & 19 & 11 & 8 & 14 \\
\hline Information & 18 & 8 & 8 & 12 & 12 \\
\hline Reference & 6 & 37 & 17 & 9 & 12 \\
\hline Operational & 4 & 4 & 8 & 8 & 7 \\
\hline Conversation & 7 & 0 & 5 & 5 & 5 \\
\hline Unknown & 6 & 0 & 0 & 2 & 2 \\
\hline Total & 100 & 100 & 100 & 100 & 100 \\
\hline
\end{tabular}

Note.-Bold values indicate the most prevalent transaction type for a given institution type (i.e., the highest value within a column). Italicized values indicate at which institution type each transaction type was most prevalent (i.e., the highest value across a row).

they received the fewest traditional reference questions at the desk, as our analysis of types of transactions next reveals. Technology transactions were the leading type of transaction in our sample, constituting 32 percent of the total transactions we observed. (See table 3, which lists the prevalence of transaction types by type of institution.) Technology transactions were the most prevalent type in public libraries (39 percent) and two-year academic libraries (37 percent) and the second most prevalent at large fouryear libraries (19 percent). An informant at Big City Public noted: "We spend an awful lot of our time helping people-signing them up for the computers, or 'this one's not working,' or 'he took my time,' or just solving computer-related things. . . . You know, 'I can't print this, what do I do?' You just go through the steps or sit there and look at the screen with them a lot of times. I mean, we don't know, but we'll figure it out: 'Well there's a little print icon there, why don't you try that?"”

Across our sample, most technology transactions concerned equipment, such as printers, fax machines, and copiers, accounting for over 40 percent of all technology transactions at large four-year libraries and 80 percent at two-year libraries. Computer reservations systems were a second major prompter of technology transactions at large four-year and public libraries. Technology transactions most directly tied to traditional reference functions, namely, those related to electronic databases and other search-related technologies, never occurred at public libraries, and at their highest they constituted (at small four-year libraries) less than 30 percent of all technology transactions. 
Circulation transactions were the second most prevalent transaction type overall, accounting for 16 percent of the total transactions, a result that was fairly constant across type of institution. At merged desks that lacked circulation staff, reference librarians were frustrated with the number of circulation questions they had to handle, as made clear in this comment by a Small City Public librarian: "I mean, good heavens, they [reference librarians] are using a cash register, they're handing out guest passes, they're creating library cards. I mean, this is clerical work."

The third most prevalent type of transaction was holdings, accounting for 14 percent of the total transactions we observed across all libraries. Holdings transactions were the most prevalent at large four-year academic libraries, where they constituted the most frequent transaction (at 24 percent) across all types. Information transactions, which constituted 12 percent of the total transactions across all libraries, were, like holdings transactions, most prevalent in large four-year libraries.

Although reference transactions stand at the core of what scholars commonly associate with reference work, these transactions represented a small portion (12 percent) of the total transactions we observed. The proportion was smallest at large four-year academic libraries, where reference transactions consisted of only 6 percent of the total transactions observed. Their numbers were only slightly greater at public libraries (9 percent) and twoyear academic libraries (17 percent). Where reference questions were prevalent was at small four-year academic libraries, constituting 37 percent of all transactions in these institutions. These libraries seemed particularly attuned to the homework and project assignments of their institutions: librarians were familiar with individual course syllabi and often guided student patrons through assignment requirements.

Overall, just under a third of reference transactions lasted more than five minutes, as seen in figure 7 , which provides a histogram of reference transaction durations. Notably, no reference transaction lasted more than five minutes at large four-year academic libraries in our sample. Small fouryear academic libraries in our sample featured the highest percentage (53 percent) of all reference transactions lasting more than five minutes. As seen in figure 8 , which displays the distribution of reference interviews by the number of questions the librarian posed, small four-year academic libraries also had the smallest percentage of reference transactions in which the librarian posed no questions (26 percent). Our data for duration and number of questions yield highly congruent results and suggest that reference interviews were rare among all transactions we observed at the reference desk. Only a third of reference transactions involved more than a single question from the librarian, which is equal to the fraction that lasted more than five minutes. These numbers indicate that reference interviews accounted for no more than 4 percent of all desk transactions. 


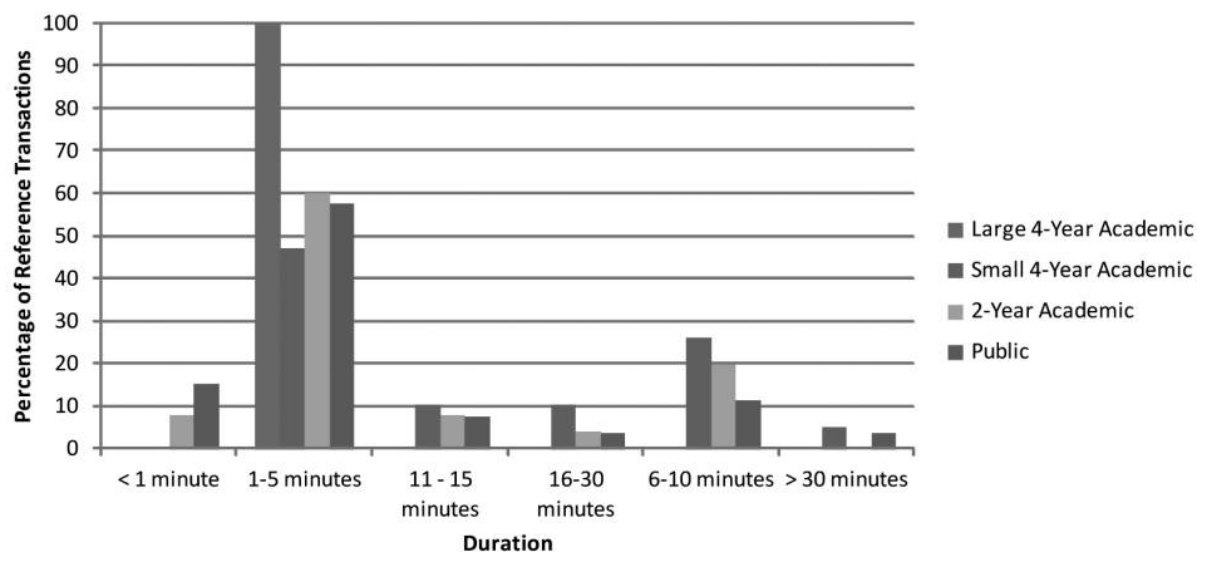

Fig. 7.-Reference interview distribution by duration and type of library (color online).

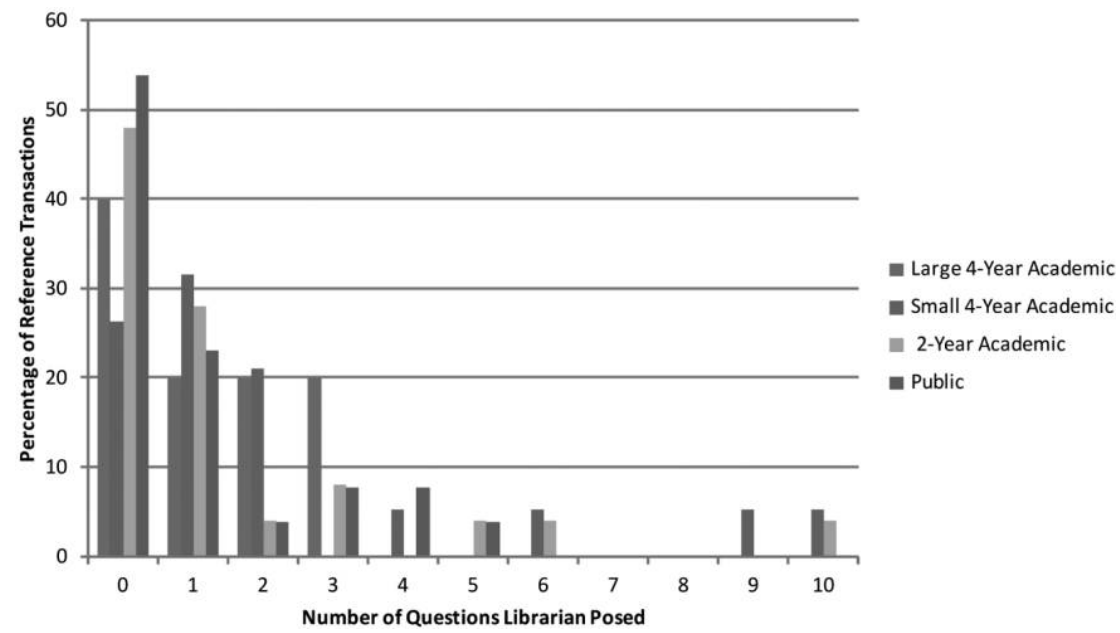

FIG. 8.-Reference interview distribution by number of questions posed and type of library (color online). 
Operations transactions and conversation transactions each constituted less than 10 percent of the total transactions we observed and were low across all institution types. A Big City Public librarian viewed computers as the reason for disciplinary transactions, which she did not relish: "I think the computers should all be in one well-lit room with someone looking down over everything like at [Big Research]. As it is, we are turning into hall monitors, and it's really frustrating."

Overall, our analysis of on-desk activities shows that large four-year academic libraries received the lowest percentage of traditional reference questions, which we suggest may have facilitated librarians' migration away from the desk in these libraries. Our analysis of off-desk activities provides evidence that supports the on-desk results: we find that librarians in fouryear academic libraries engaged in the broadest range and the greatest number of off-desk activities as compared to other librarians in our sample.

\section{Away from the Desk: Technology as Creative Muse}

Table 4 shows the number of libraries in which reference librarians engaged in each off-desk activity. Collection development and library instruction (each undertaken at eight out of nine libraries) topped this list. Judging from our informants' comments, library instruction consumed more of reference librarians' time than did collection development and was a key aspect of their role. At Big Comprehensive, the time devoted to instruction was great enough to warrant a change in job title: reference librarians became known as "information and learning services" librarians. A librarian noted: "Instead of referring people we are now trying to teach them the difference of all the noise out there, trying to get that approach across."

Several informants indicated that their library instruction responsibilities had increased over the years with the introduction of technology in the library. This comment from a librarian at Small Comprehensive reflects that sense of change: "We've started to offer more instruction. Instead of just giving a tour of the library we have classes come in and show them the resources. And you pretty much need to, with the databases and the online catalog and all." At Big Research, a librarian remarked: "[In the past] you would have to go to Webster's Third Unabridged Dictionary and look up words for people and read the definitions to them over the phone. They do all that kind of stuff for themselves now. We do a lot more instruction, one-on-one guidance on using the databases, helping students select which databases they need to use."

Patron meetings (six out of nine libraries) were the next most commonly reported off-desk activity. Reference librarians' meeting with students and faculty off the reference desk enabled them to assist students with projects and to communicate with faculty about library resources. Although com- 
TABLE 4

Off-Desk Activities by Type of Library

\begin{tabular}{|c|c|c|c|c|c|}
\hline \multirow[b]{2}{*}{ Off-Desk Activity } & \multicolumn{5}{|c|}{ Types and Numbers of Libraries } \\
\hline & $\begin{array}{c}\text { Large } \\
\text { Four-Year } \\
\text { Academic } \\
\text { Libraries } \\
\text { (2 Total) }\end{array}$ & $\begin{array}{c}\text { Small } \\
\text { Four-Year } \\
\text { Academic } \\
\text { Libraries } \\
\text { (2 Total) }\end{array}$ & $\begin{array}{l}\text { Two-Year } \\
\text { Academic } \\
\text { Libraries } \\
(3 \text { Total })\end{array}$ & $\begin{array}{c}\text { Public } \\
\text { Libraries } \\
\text { (2 Total*) }\end{array}$ & $\begin{array}{c}\text { Overall } \\
\left(9 \text { Total }^{*}\right)\end{array}$ \\
\hline Collection development & 2 & 1 & 3 & 2 & 8 \\
\hline Library instruction & 2 & 2 & 3 & $1^{\dagger}$ & 8 \\
\hline Patron meetings & 2 & 2 & 1 & 1 & 6 \\
\hline Technical work & 2 & 0 & 1 & 2 & 5 \\
\hline Outreach & 2 & 0 & 2 & 1 & 5 \\
\hline Library tours & 1 & 2 & 0 & 0 & 3 \\
\hline Committee membership & 1 & 0 & 1 & 0 & 2 \\
\hline Cataloging & 0 & 0 & 1 & 0 & 1 \\
\hline Interlibrary loan & 1 & 0 & 0 & 0 & 1 \\
\hline $\begin{array}{l}\text { Total no. activities by } \\
\text { institution type }\end{array}$ & 13 & 7 & 12 & 7 & 39 \\
\hline $\begin{array}{l}\text { Average no. activities per } \\
\text { library }\end{array}$ & 6.5 & 3.5 & 4 & 3.5 & 4.3 \\
\hline $\begin{array}{l}\text { Total no. unique activities } \\
\text { by institution type }\end{array}$ & 8 & 4 & 7 & 6 & 9 \\
\hline
\end{tabular}

* One public library dropped out of the study after the on-desk observations were completed and before we carried out the study of off-desk activities, thus reducing the number of public libraries in our sample to two and the number of total libraries to nine.

+ The public library in which reference librarians conducted no information literacy classes had separate adult or public service librarians who were responsible for offering such courses.

mon across our sample, patron meetings did not appear to be so frequent as to reflect the primacy of the reference interview in off-desk duties, with private conference rooms simply replacing the reference desk. Rather, individual off-desk patron meetings seemed to come as welcome complements to other activities, including instruction, collection development, and technical work activities, which followed next on the list by occurring at five libraries.

With the expansion of the Internet and the World Wide Web, librarians engaged in a variety of technical work activities to serve patrons, including creating widgets for library web pages, blogging, and developing virtual library communities. Many of our informants were excited about these activities and were eager to show us their creations. As illustration, a librarian from Small City Public proudly pointed out a widget he created on his library's web page: "Well, it's a book letters widget for rotating staff picks. I made it by altering a little code on Grease Monkey."

Not everyone, however, appreciated the opportunity to develop and prac- 
tice technical computer skills. A librarian at Big Comprehensive expressed mixed feelings:

It used to be that companies would hand you their product and you used it, such as the text-based catalogs. These days companies hand you something pretty close and you get to tweak it, which is nice in a lot of ways. But it is very time consuming and very buggy in some ways. . . Now we have to do a lot of behind-the-scene things. . . . It's just not, it's just more [groans] intense . . . because you don't know why something is not happening. Back in ancient times, I thought, "I don't want to be a computer programmer because I don't want to sit and stare at a screen all day." Well, guess what? Now I'm getting paid half of what they are getting. . . . That is where the real frustration comes in because I'm kind of older and I didn't start out with this. I didn't have this in library class.

Outreach activities also arose at five libraries, with four-year academic libraries leading the charge. A Big Research librarian explained:

We were the gatekeepers, and students were forced to come here in the old days. . . . But now, with the online power that Google and other search engines have, they don't have to come to us, so we have to reach out to the students and sell ourselves. . . . We have a welcome table at the beginning of the semester. In February, we're going to have a valentines table set up. These are all activities to draw the students in. . . We didn't have to do that in the old, printed index days because it was mandatory, it was us or the highway, they couldn't get it done without us. But now you can actually write a paper off of Wikipedia and Google. . . So we're trying to go out there and show them additional options they might not know about, these paid databases that don't always surface in Google, and full content that we bought specifically for them that they may not know about. So outreach is a bigger component of what we do now than in the past.

Joining up with civic and national organizations to promote books and reading formed another form of outreach. A Big City Associate informant pointed out: "We've been having a lot of exhibits for 'The Big Read' [an IMLS-sponsored event]. . . . I am going to bring a few decorations for the horror exhibit in that display case [a display case that has horror books in it]." A Big City Public librarian laid bare the reasons for her library's outreach efforts: "Well, we are trying to stay relevant to the community. Actually we're trying to keep our jobs . . . the taxpayers pay us." This motivation perhaps explains the occurrence of events such as salsa dance lessons that we saw advertised at Small Town Public.

Librarians at only a few libraries mentioned conducting other off-desk activities. Informants added library tours, committee membership, cataloging, and interlibrary loan activities to their list of off-desk duties at less than one-third of the libraries in our sample. 


\section{Three Approaches to Technological Change}

In teasing out the effect of technological change on and off the reference desk, our findings provide the broad contours of three distinct approaches that libraries took in response to significant technological advances. We term these three approaches role reinvention, structural defense, and resigned surrender. Our emergent analytical framework suggests that institutional setting strongly shaped libraries' choice of approach.

The first approach, role reinvention, was a "run and regroup" strategy that distanced librarians from their position at the reference desk and altered their tasks and responsibilities through the addition of myriad offdesk activities. This approach characterized the large four-year academic libraries in our study. Librarians in this setting worked the fewest hours on the desk across our sample, with paraprofessionals and student employees largely assuming their desk duties. The low hours for reference librarians reflected a dramatic decrease from the 1990s, when time at the desk was double what it is today.

In lieu of answering questions at the desk, reference librarians in these libraries engaged in the broadest range of, and the greatest number of, off-desk activities in our sample. Table 4 shows that librarians in large fouryear academic libraries participated, on average, in six and a half different off-desk activities; the next closest value in our sample was four activities by librarians in two-year academic libraries. Similarly, large four-year academic libraries featured eight unique activities out of a total nine possible activities, constituting the highest value across our sample.

By forging a new occupational role, these librarians enacted a model of reference in which change took on a largely positive hue. Two significant changes characterized this new model. First, the skills and knowledge of reference librarians were both less specialized and more technical than in the past. Librarians were no longer hired for their knowledge in subject matter domains that mirrored the expertise of university departments and colleges, such as geology or humanities. Rather, under this approach, libraries looked for new hires with strong communication, presentation, and instruction skills. In addition, libraries expected new hires to have considerable technical skills, such as knowledge of computer programming. A Big Research librarian explained:

When I started back in the old days, they [libraries] were very much focused on what your undergraduate background was in, what your advanced degrees were in. ... If they were going to hire a chemistry librarian, they wanted to hire a chemist, if they wanted to hire a geology librarian, they wanted to hire a geologist. . . . Now, they don't care about that at all. . . . You need to know the buzz words . . . but you don't need to do research in geology in order to work as a librarian. Now, we need to hire people who are good in front of groups, people who are able to instruct, 
have presentation skills, people that have computer skills and computer literacy ... people that can self-teach themselves on the latest technologies and be a good instructor and public speaker. Those are skills that are much more important to us than some degree in geology or whatever.

These changes in skills and knowledge fed directly into the second major change under role reinvention: armed with skills in instruction and technology, librarians shifted from a largely one-to-one interaction with individual patrons to a one-to-many arrangement in which they helped groups or collections of patrons develop skills and techniques rather than handing them specific, found knowledge. This one-to-many teaching could be synchronous and face-to-face, as when librarians taught classes about how to use new reference tools, or asynchronous and virtual, as when librarians created LibGuides to direct patrons to new sources.

In some sense, this change in the nature of patron interaction engendered a depersonalization of traditional reference: in lieu of a preponderance of one-to-one interactions aimed at satisfying unique reference requests, more general interactions aimed at providing help for a broader audience became the norm. As a consequence of these changes, the reference interview lost its central position in the definition of the occupation under role reinvention. Librarians came to rely less on the interviewing skills of how to tease the question out of the patron and more on the skills of a guide to help the patron become a better independent inquirer.

Small four-year academic libraries were the site of the second approach that our data revealed, structural defense. Structural defense was a "stay and fight" strategy that maintained the status quo through adjustments in how librarians provided reference services. Libraries that employed this approach prevented large-scale occupational transformation via structural changes that preserved the reference desk as the locus for substantive questions. These structural changes included having a desk whose physical design invited patrons to sit and engage in lengthy interactions, operating a self check-in system for computers rather than a reservation system managed by the reference staff, having circulation staff on hand in a merged desk format to answer circulation questions, and stationing technical staff immediately nearby to deal with computer and equipment needs. One Big Research librarian who had formerly worked at Small Comprehensive explained the difference in desks' physical structure: "First of all, it's just the height of the desk. At Small Comprehensive the desk is a normal height and students sit down and get out all their notes and their books and prepare for like an hour-long session. They ask all kinds of questions about their research and finding scholarly sources and formatting their citations. ... Here [at Big Research] . . . it is the height of the desk. People stand, 
they don't sit, and it is just a 'drive-through' scenario. Some people barely slow down as they are walking by to ask their question."

By routing nonreference queries to other staff, the structural defense approach granted librarians the least busy desks in our sample as well as an environment conducive to the question-and-answer format of the standard reference interview. The results were clear: these libraries experienced the longest duration reference transactions and had the highest percentage of questions posed by the librarian across our sample. Consequently, as seen in table 4, they were also engaged in the smallest number of off-desk activities.

Under the structural defense approach, librarians learned to work with new technologies, but they did not experience the kind of dramatic change in knowledge and skills as librarians did under the role reinvention approach. The librarians' role, therefore, seemed touched by, but largely unchanged by, technological advance. Librarians under the structural defense approach essentially maintained the traditional reference role, aiding patrons one-on-one with information queries.

Resigned surrender constituted the third approach in our data and reflected perhaps less a strategy than an outcome of "stay and endure." Twoyear academic libraries and public libraries evinced this approach. Because administrators in these settings were unable or unwilling to make staffing or structural changes to adapt to technological change, their librarians were the most likely across our sample to be caught in the downside of technological change. With few technical or circulation staff to ward off nonreference transactions, these librarians coped with the onslaught of technology queries. Consequently, they engaged in few reference transactions, of which only a small percentage were of long duration or required them to ask a probing, interview-type question.

As under the role reinvention approach, librarians under the resigned surrender approach saw their skill set change dramatically. But whereas librarians under the former developed new technology skills to build websites, write programming code for library aids, or learn new software applications, librarians under the resigned surrender approach gained technology skills that were mundane in comparison, such as fixing the various malfunctions experienced by printers, fax machines, and scanners that the patrons employed. A Small City Public librarian attributed the acquisition of these low-end technology skills to patrons' job struggles in a tight economy:

We've noticed just recently with the recession there are so many people coming to apply for jobs and, you know, [the jobs] are all online jobs, there are no paper applications anymore. And some of these folks [are] just so illiterate [taps desk emphatically] when using a mouse or anything, 
and we almost have to walk them through and sit down and fill out the application form. . . . We feel like, "OK, we are here to serve, but at some level they [employers] are doing that for a reason, too: to weed out people who can't work a computer." So we are actually helping them [patrons] by filling it out, then they go get the job, and they didn't even know how to work the cash register, which is all computerized.

Overall, rather than forging a new occupational role (as per the role reinvention approach) or maintaining the traditional reference role (as per the structural defense approach), the librarians under the resigned surrender approach were granted little institutional leeway to deal with technological change and consequently they experienced adverse role changes.

\section{Conclusion}

Like most qualitative studies, our study drew upon a relatively small sample of informants and, as a result, our findings should be viewed as preliminary. Yet, our comparison of reference work at ten libraries helps reconcile competing perspectives on the future of reference librarianship (and divergent interpretations of the impact of technology on this occupation) that populate the librarianship literature. It does so by suggesting a fit between institutional setting and a library's approach to technological change.

Large, four-year academic libraries in our study had educated patrons who were perhaps well positioned to be successful independent inquirers. The skill of the patrons, combined with the aid of paraprofessionals and student employees, enabled librarians in this setting to leave the reference desk when technology dramatically altered the balance in the types of questions that patrons posed. Through a wide array of off-desk activities, these librarians engaged in role reinvention of the type envisioned by scholars such as Devries and Rodkewich [36], who spoke of a transformation in how reference librarians viewed themselves, a transformation that involved a shift in occupational identity from information provider to guide or facilitator.

By contrast, two-year academic and public libraries spoke of budget cuts that kept them working long hours on the desk. Their patrons were less fluent than four-year degree students with new technologies and demanded constant trouble-shooting aid. Thus, even though librarians in these settings engaged in high-end technical activities (e.g., they created online modules from information literacy class materials), the time they could spend away from the desk was limited. The end result was resigned surrender, by which librarians, with a mandate to serve the public, saw their skills wane in the face of endless attendance on equipment.

At a time when large-scale surveys such as the Public Libraries and the 
Internet series report that public libraries increasingly form a bridge across the digital divide for patrons who have limited online access and digital literacy, and when initiatives like the IMLS's recent Digital Inclusion Framework point to libraries as key providers of broadband technologies that allow all citizens to fully participate in government, health, employment, and other forums in a digital society, data from our study suggest that public librarians may be overwhelmed with the practical issues of handling routine hardware and software problems for patrons with low-level skills in support of these loftier goals. Our results for two-year and public libraries mirror the observations of Charles Anderson and Peter Sprenkle [58, p. 45], who, after a year-long observation of the reference desk in a public library noted, "It is difficult to think of any library problem before computers that can equal the sheer staff frustration of keeping these myriad pieces of equipment functioning." In an environment in which librarians and patrons alike struggle to see the forest (information) for the trees (equipment), the outcome under resigned surrender resonates with the dire forecasts of those who see a bleak future for reference librarianship [e.g., 48, 59].

Finally, small four-year libraries drew upon their intimate setting, close relations with professors, and familiarity with class assignments to restructure work in ways that maintained the dominion of the reference interview and the frequency of substantive reference transactions. Their structural defense approach significantly limited the impact of technological change on reference librarians' work and role. In so doing, it gives credence to claims for the continued relevance of the reference interview [4-7]. Of the three approaches that we observed, the structural defense approach best maintained the ideal of personal assistance to inquirers that has characterized conceptions of reference work since the emergence of this field more than a century and a quarter ago [26].

In short, institutional factors like patron audiences, library mandates, and financial situations strongly shaped libraries' approach to technological change. These differences in how libraries dealt with technological change engendered differences in reference librarianship itself. For example, the criticality of the reference interview was markedly different across the three approaches. Under the role reinvention approach favored by large four-year libraries, the reference interview waned in importance, as it did under the resigned surrender approach of two-year academic and public libraries. Only under the structural defense approach of small fouryear libraries was the reference interview a highly critical aspect of this work.

Patron engagement also looked very different across approaches. Under structural defense and resigned surrender, librarians' engagement with patrons was personal, often face to face, and typically one to one. Under the former, however, the engagement tended to be of much higher du- 
TABLE 5

Characteristics of Approaches to Technological Change IN REFERENCE LIBRARIANSHIP

\begin{tabular}{|c|c|c|c|}
\hline \multirow[b]{2}{*}{ Characteristic } & \multicolumn{3}{|c|}{ Approach } \\
\hline & Role Reinvention & Structural Defense & Resigned Surrender \\
\hline Strategy/outcome & Run and regroup & Stay and fight & Stay and endure \\
\hline Institutional setting & $\begin{array}{l}\text { Large four-year } \\
\text { academic libraries }\end{array}$ & $\begin{array}{l}\text { Small four-year } \\
\text { academic libraries }\end{array}$ & $\begin{array}{l}\text { Two-year academic } \\
\text { and public } \\
\text { libraries }\end{array}$ \\
\hline $\begin{array}{l}\text { Criticality of reference } \\
\text { interview }\end{array}$ & Low & High & Low \\
\hline Patron engagement & $\begin{array}{l}\text { Impersonal, } \\
\text { asynchronous, } \\
\text { one to many }\end{array}$ & $\begin{array}{l}\text { Personal, face to } \\
\text { face, one to } \\
\text { one, long } \\
\text { duration }\end{array}$ & $\begin{array}{l}\text { Personal, face to } \\
\text { face, one to } \\
\text { one, short } \\
\text { duration }\end{array}$ \\
\hline Skills and knowledge & $\begin{array}{l}\text { Instruction and } \\
\text { high-end technical }\end{array}$ & Subject matter & $\begin{array}{l}\text { Instruction and } \\
\text { low-end technical }\end{array}$ \\
\hline Role & Guide & Expert & Trouble-shooter \\
\hline
\end{tabular}

ration than under the latter in that a reference interview generally took longer than instructions on how to print a document. Under role reinvention, by contrast, librarians' engagement with patrons was frequently impersonal, asynchronous, and one to many.

Similar changes marked the knowledge and skills that the position demanded. Only under structural defense did librarians' skills and knowledge remain firmly rooted in subject matter expertise, in line with a view that holds reference service to still be the most valued task that reference librarians perform $[15,16]$. Under the other two approaches, technical and instruction skills became dominant, as borne out by numerous studies of job ads $[13,18,19]$. Under role reinvention, these technical skills tended to be high-end and facilitative of creative work, such as the construction of web pages. Under resigned surrender, technical skills tended to be lowend and mundane, focusing more on the correction of equipment malfunction.

Ultimately, each approach yielded a distinct role for the reference librarian. Under role reinvention, the reference librarian became a guide who aided independent inquirers. Under structural defense, the reference librarian remained, for the most part, a subject matter expert. Under resigned surrender, the reference librarian was reduced to trouble-shooter. Table 5 summarizes these characteristics of reference librarianship by type of approach.

That a given approach fits an institution does not guarantee that it will equally well fit all of the librarians within that institution, which raises 
issues of training and education. The role reinvention approach, in particular, calls on librarians to develop new talents in a variety of often technical arenas. Several of our informants noted that they felt unprepared in terms of their own education for taking on these new tasks. By detailing the responsibilities that reference librarians bear across library settings, our study begins to inform conversations about how faculty ought to teach modern reference and prepare librarians for work. (See [60].)

Although institutional factors may strongly shape libraries' approaches, they do not determine them. Public and two-year academic libraries in our sample could have chosen, for example, to veer away from a resigned surrender approach via the undertaking of structural changes that would have preserved the sanctity of the reference desk. Taking a different tack, these libraries could have hired additional paraprofessionals to staff the reference desk, freeing librarians to follow a role reinvention approach. Both of these alternatives, however, would have increased labor costs and, thus, may have been prohibitive for these libraries.

Notably, absent a workforce restructuring of some type, the status quo arrangement is likely to result in what is arguably the least favorable outcome, resigned surrender. The larger lesson from our study, then, may be that libraries ought to take proactive steps to avoid the potential negative impact of technological change on reference librarianship. By detailing the outcomes of three different approaches, our study may provide some guidance in what institutional factors may be necessary to support a library's preferred outcome. Future research might contribute to this endeavor by broadening the sample of libraries beyond the ten libraries in our study and by investigating other institutional factors beyond the ones that emerged in observations and interviews with our informants.

\section{REFERENCES}

1. Jennerich, Edward J., and Jennerich, Elaine Z. "Teaching the Reference Interview." Journal of Education for Librarianship 17, no. 2 (Fall 1976): 106-11.

2. Dervin, Brenda, and Dewdney, Patricia. "Neutral Questioning: A New Approach to the Reference Interview." Research Quarterly 25, no. 4 (Summer 1986): 506-13.

3. Ross, Catherine Sheldrick. "The Reference Interview: Why It Needs to Be Used in Every (Well, Almost Every) Reference Transaction." Reference and User Services Quarterly 43, no. 1 (Fall 2003): 38-43.

4. Abels, Eileen G. "The E-mail Reference Interview." Reference Quarterly 35, no. 3 (Spring 1996): 345-58.

5. Straw, Joseph E. "A Virtual Understanding: The Reference Interview and Question Negotiation in the Digital Age." Reference and User Services Quarterly 39, no. 4 (Summer 2000): 376-79.

6. Westbrook, Lynn. "Virtual Reference Training: The Second Generation." College E Research Libraries 67, no. 3 (May 2006): 249-59. 
7. Luo, Lili. "Toward Sustaining Professional Development: Identifying Essential Competencies for Chat Reference Service." Library and Information Science Research 30, no. 4 (2008): 298-311.

8. Martell, Charles. "The Elusive User: Changing Use Patterns in Academic Libraries, 1995 to 2004." College $\mathcal{E}$ Research Libraries 68, no. 5 (September 2007): 435-45.

9. Applegate, Rachel. "Whose Decline? Which Academic Libraries are 'Deserted' in Terms of Reference Transactions?" Reference and User Services Quarterly 48, no. 2 (Winter 2008): $176-89$.

10. Henry, Deborah B., and Neville, Tina M. "Testing Classification Systems for Reference Questions." Reference and User Services Quarterly 47, no. 4 (Summer 2008): 364-73.

11. Ryan, Susan M. "Reference Transactions Analysis: The Cost-Effectiveness of Staffing a Traditional Academic Reference Desk." Journal of Academic Librarianship 34, no. 5 (2008): 389-99.

12. Hardy, Georgina, and Corrall, Sheila. "Revisiting the Subject Librarian: A Study of English, Law and Chemistry." Journal of Librarianship and Information Science 39, no. 2 (June 2007): 79-91.

13. Goetsch, Lori. "Reinventing Our Work: New and Emerging Roles for Academic Librarians." Journal of Library Administration 48, no. 2 (2008): 157-72.

14. Manjarrez, Carlos A.; Ray, Joyce; and Bisher, Karmen. "A Demographic Overview of the Current and Projected Library Workforce and the Impact of Federal Funding." Library Trends 59, nos. 1-2 (Summer/Fall 2010): 6-29.

15. Buttlar, Lois, and Du Mont, Rosemary. "Library and Information Science Competencies Revisited." Journal of Education for Library and Information Science 37, no. 1 (Winter 1996): $44-62$.

16. McAbee, Sonja L., and Graham, John-Bauer. "Expectations, Realities, and Perceptions of Subject Specialist Librarians' Duties in Medium-Sized Academic Libraries.” Journal of Academic Librarianship 31, no. 1 (January 2005): 19-28.

17. Schreiner-Robles, Rebecca, and Germann, Malcolm. "Workload of Reference-Bibliographers in Medium-Sized Academic Libraries." Reference Quarterly 29, no. 1 (Fall 1989): 8291.

18. White, Gary W. "Academic Subject Specialist Positions in the United States: A Content Analysis of Announcements from 1990 through 1998." Journal of Academic Librarianship 25, no. 5 (September 1999): 372-82.

19. Lynch, Beverly P., and Smith, Kimberley Robles. "The Changing Nature of Work in Academic Libraries." College $\mathcal{E}$ Research Libraries 62, no. 5 (September 2001): 407-20.

20. Lynch, Mary Jo. "Reference Interviews in Public Libraries." Library Quarterly 48, no. 2 (1978): 119-42.

21. Hauptman, Robert. "Computers, Reference, and Revolution." Reference Librarian 2, nos. 5-6 (1982): 71-75.

22. Harris, Roma M. "Gender and Technology Relations in Librarianship." Journal of Education for Library and Information Science 40, no. 4 (Fall 1999): 32-246.

23. Institute of Museum and Library Services (IMLS). "Status of Technology and Digitization in the Nation's Museums and Libraries: 2002 Report." IMLS, Washington, DC, May 10, 2002. http://www.imls.gov/resources/TechDig02/2002Report.pdf.

24. Breeding, Marshall. "Using Technology to Enhance a Library as Place." Computers in Libraries 31, no. 3 (April 2011): 29-31.

25. Kupersmith, John. "Technostress and the Reference Librarian." Reference Services Review 20, no. 2 (1992): 7-50.

26. Rothstein, Samuel. "The Measurement and Evaluation of Reference Service." Library Trends 12, no. 1 (January 1964): 456-72. 
27. Janes, Joseph. "Digital Reference: Reference Librarians' Experiences and Attitudes.” Journal of the American Society for Information Science and Technology 53, no. 7 (2002): 549-66.

28. Balay, Robert, and Andrew, Christine. "Use of the Reference Service in a Large Academic Library." College $\mathcal{E}$ Research Libraries 36, no. 1 (January 1975): 9-26.

29. Sorgenfrei, Robert, and Hooper-Lane, Christopher. "Book Selection Responsibilities for the Reference Librarian: Professional Benefit or Burden?” Library Collections, Acquisitions, and Technical Services 25, no. 2 (Summer 2001): 171-78.

30. Cardina, Christen, and Wicks, Donald. "The Changing Roles of Academic Reference Librarians Over a Ten-Year Period." Reference and User Services Quarterly 44, no. 2 (Winter 2004): 133-42.

31. Becker, Joseph. "Libraries, Society, and Technological Change." Library Trends 27, no. 3 (Winter 1979): 409-19.

32. Hallman, Clark N. "Technology: Trigger for Change in Reference Librarianship.” Journal of Academic Librarianship 16, no. 4 (September 1990): 204-8.

33. Boaz, Martha. "USC Library Education Institute Summary." Journal of Education for Librarianship 2, no. 2 (Fall 1961): 68-76.

34. Kenyon, Carleton W. "The Mission of the Legal Reference Librarian." Law Library Journal 58 (1965): 126-29.

35. Howard, Jennifer. "College Librarians Look at Better Ways to Measure the Value of Their Services." Chronicle of Higher Education, April 1, 2011. http://chronicle.com /article/College-Librarians-Look-at/126975/?sid=wc?sid=wc.

36. DeVries, Joann, and Rodkewich, Patricia. "Master Reference Librarians for a New Age: A Study of Characteristics and Traits." Reference Librarian 28, no. 59 (1997): 203-14.

37. Bauner, Ruth E. "Reference Ready beyond the M.L.S." Reference Librarian 13, no. 30 (1990): 45-58.

38. Massey-Burzio, Virginia. "Education and Experience: Or, the MLS Is Not Enough." Reference Services Review 19, no. 1 (Spring 1991): 72-73.

39. Mathews, Janie M., and Pardue, Harold. "The Presence of IT Skill Sets in Librarian Position Announcements." College $\mathcal{E}$ Research Libraries 70, no. 3 (May 2009): 250-57.

40. Wang, Hanrong; Tang, Yingqi; and Knight, Carley. "Contemporary Development of Academic Reference Librarianship in the United States: A 44-Year Content Analysis.” Journal of Academic Librarianship 36, no. 6 (November 2010): 489-94.

41. O'Gorman, Jack, and Trott, Barry. "What Will Become of Reference in Academic and Public Libraries?" Journal of Library Administration 49, no. 4 (May 2009): 327-39.

42. Emmick, Nancy J. "Nonprofessionals on Reference Desks in Academic Libraries." Reference Librarian 4, no. 12 (Spring/Summer 1985): 149-60.

43. Courtney, Nancy. "Evaluating the Use of Paraprofessionals at the Reference Desk." College and Undergraduate Libraries 8, no. 1 (2001): 31-40.

44. McKinzie, Steve. "For Ethical Reference, Pare the Paraprofessionals." American Libraries 33, no. 9 (October 2002): 42.

45. St. Clair, Jeffrey W., and Aluri, Rao. "Staffing the Reference Desk: Professionals or Nonprofessionals?" Journal of Academic Librarianship 3, no. 3 (July 1977): 149-53.

46. Dinkins, Debbi, and Ryan, Susan M. "Measuring Referrals: The Use of Paraprofessionals at the Reference Desk." Journal of Academic Librarianship 36, no. 4 (July 2010): 279-86.

$\rightarrow$ 47. Su, Mila. "Beyond Circulation: The Evolution of Access Services and Its Relationship to Reference Librarianship." Reference Librarian 49, no. 1 (2008): 77-86.

48. Ewing, Keith, and Hauptman, Robert. "Is Traditional Reference Service Obsolete?" Journal of Academic Librarianship 21, no. 1 (January 1995): 3-6.

49. Smith, Debbi A., and Oliva, Victor T. "Becoming a Renaissance Reference Librarian in Academe: Attitudes toward Generalist and Subject Specific Reference and Related Profession Development." Reference Services Review 38, no. 1 (2010): 125-51. 
50. Boyd, Rhonda S. "Assessing the True Nature of Information Transactions at a Suburban Library." Public Libraries 44, no. 4 (July/August 2005): 234-40.

51. Glaser, Barney G., and Strauss, Anselm L. The Discovery of Grounded Theory: Strategies for Qualitative Research. New York: Aldine, 1967.

52. Miles, Matthew B., and Huberman, A. M. Qualitative Data Analysis: A Source Book of New Methods. Beverly Hills, CA: Sage, 1984.

53. Strauss, Anselm L., and Corbin, Juliet M. Basics of Qualitative Research: Grounded Theory Procedures and Techniques. Newbury Park, CA: Sage, 1990.

54. Salisbury, Linda; Toombs, H. Sylvia; Kelly, Elizabeth A.; and Crawford, Susan. "The Effect of End-User Searching on Reference Services: Experience with MEDLINE and Current Contents." Bulletin of the Medical Library Association 78, no. 2 (1990): 188-91.

55. Arndt, Theresa S. "Reference Service without the Desk." Reference Services Review 38, no. 1 (2010): 71-80.

56. Tyckoson, David A. "Issues and Trends in the Management of Reference Services: A Historical Perspective." Journal of Library Administration 51, no. 3 (2011): 259-78.

57. Singer, Carol A. "Ready Reference Collections: A History." Reference and User Services Quarterly 49, no. 3 (2010): 253-364.

58. Anderson, Charles R., and Sprenkle, Peter. Reference Librarianship: Notes from the Trenches. New York: Haworth, 2006.

59. Hauptman, Robert. "The Myth of the Reference Interview." Reference Librarian 6, no. 16 (1987): 47-52.

60. Roy, Loriene. "We Begin Our Conversation: Let's Talk about Education for Reference Librarians." Reference Librarian 51, no. 3 (July-September 2010): 245-47. 